\title{
Degradasi Lahan dan Solusinya di Provinsi Riau, Indonesia
}

\author{
Elviriadi $^{1}$, M Sangap Siregar ${ }^{2}$ \\ ${ }^{1}$ Dosen Fakultas Pertanian dan Ilmu Hewan Universitas Islam Negeri Sultan Syarif Kasim Riau \\ E mail: Centrefuture@yahoo.co.id \\ ${ }^{2}$ Dosen Prodi Kesmas STIKes Hang Tuah Pekanbaru Riau \\ Email : mssiregarma@gmail.com
}

\begin{abstract}
Characteristic of Land degradation in Riau Province in the study can be viewed as any change or disturbance to the land perceived to be deleterious or undesirable area, loss of the biological and loss of natural vegetation, local economic productivity and complexity of rain-fed cropland, urban sprawl, irrigated cropland, forest and commercial development combination of processes arising from company/human activities. The conclusion was based on peat in Riau severe damage as a result of the drying system with the creation of canalization that followed the burning of forests and massive land over the last 17 years. As a result, a decline in Riau land of which $90 \%$ is the deepest tropical peat swamp in the world. Data analysis based on the results of the observation that has been going on for one year found severe damage to turf conditions Riau has been uneven in some areas. Damage to peat mainland Riau impact on the soil surface as is the case in Kalimantan, which is about 2 centimeters (cm) per year. Result and discussion revealed some of solutions to address the threat of damage due to the sinking of Riau burning peat. 1). "Rewetting" technique. 2) Back to traditional ecological knowledge management from the indigenous people. Whatever, this research refer for government to rseformation policy mindset; from the economic (oil palm plantation) oriented to promote the balance of nature and sustainability development.
\end{abstract}

\section{Key Words: Burning Peat, Rewetting Technique, Traditional Ecological Knowledge,} Land Degradation

Penelitian ini melihat tanah gambut hutan dan hilangnya salah satu provinsi Indonesia ini karbon lebih dari 25 tahun (1982-2007) dan bagaimana pemulihan degradasi tanah kami. Provinsi ini adalah Riau, rumah bagi harimau Sumatera yang terancam punah dan gajah. Laporan ini mendokumentasikan deforestasi dan degradasi hutan alam, yang didorong oleh produksi kayu pulp dan kelapa sawit, dan menunjukkan bagaimana kegiatan ini telah menyebabkan dekomposisi dan pembakaran tanah yang kaya karbon di Riau. Laporan ini juga model dua skenario untuk deforestasi hingga tahun 2015.

Alert api di Indonesia telah melonjak secara dramatis dalam beberapa hari terakhir, melonjak bahkan lebih tinggi dari wabah krisistingkat Juni 2013. Maret 2014 dan November 2014. Satelit feed ditampilkan padaGlobal Forest Watch Kebakarantelah mencatat ribuan alert api keyakinan tinggi selama dua minggu terakhir, memuncak pada 1189 pada tanggal 8
September, melebihi puncak tertinggi dalam dua tahun terakhir.

Keberadaan tanah komunal adat; tanah atau tanah tempat penampungan setiap bentuk kearifan tradisional bersama-sama ada di darat, laut, hutan, sungai, sawah, ke tatanan sosial dan harmoni sesama warga. Di atas ini adalah tradisional komunal tanah-ide ide kebajikan dalam berurusan dengan alam sekitar pertemuan pemikiran yang jernih tradisional dari elders.Nature tradisional tidak untuk kepentingan material, demi hanya manusia dan makhluk hidup lainnya, tetapi berfungsi sebagai sumber inspirasi bagi humanisasi makhluk, pikiran, dan mempertinggi sifat. Perenungan makrokosmos keheningan alam mengembangkan ide untuk membuat sajak, saran budaya, "Seloka, petatah" pepatah, dan sumber nilai publik asli. Dengan perspektif humanis sedemikian rupa, maka teori baru ini menang menerima harapan inspirasi, menciptakan cucu masa depan suatu hari nanti. 
Praktek pengelolaan hutan yang inovatif, berdasarkan pengetahuan tradisional dan dikembangkan oleh masyarakat lokal di Kabupaten, Riau Indonesia, telah memberikan kontribusi signifikan terhadap warisan alam dan budaya dunia dengan menciptakan dan memelihara lanskap luar biasa keindahan sambil membantu untuk mempertahankan produksi beberapa barang dan jasa yang meningkatkan keamanan mata pencaharian dan kualitas hidup. Tradisional ekologi pengetahuan (hutan atau sungai di daerah studi) merupakan komponen integral dari jaringan keterkaitan dan hubungan, didukung oleh kerangka keseluruhan tandatanda dan makna. Hal ini sering didasarkan pada pengalaman panjang sejarah dan wawasan yang mendalam dinamika ekosistem hutan, dan perilaku dan karakteristik spesies hewan dan tumbuhan yang ekonomi, sosial, budaya, dan spiritual makna khusus bagi masyarakat. Ulasan ini merekomendasikan adalah ketika nilai-nilai tradisional dapat dikombinasikan dengan manajemen yang bijaksana dari pemerintahan modern, dapat ditemukan dalam konsep pembangunan berkelanjutan.

Konseptualisasi kelestarian lingkungan pada pengetahuan tradisional di kosmologi Melayu berdasarkan keyakinan diartikulasikan melalui berbagai media.

Temuan yang tepat dari pengorganisasian masyarakat Melayu dan Melayu konsep puisi melambangkan kesopanan di alam. ekspresi yang indah memberikan pesan yang bermakna dalam sistem keluarga, tetangga, masyarakat dan bangsa. Komponen laut, darat dan langit sebagai sistem totalitas tidak terlepas dari sistem manusia yang sinyal kebiasaan, hukum, dan iman diperkuat pagar bahwa orang-orang dari segala macam godaan, cobaan, dan serangan yang terbentang di depan.

Provinsi Riau, di Sumatera bagian tengah, ditutupi oleh lahan gambut yang luas diperkirakan memiliki toko terbesar di Indonesia karbon. hutan yang masih tersisa Riau adalah rumah bagi terancam punah Sumatera harimau

nd gajah. Ditemukan di tempat lain di Bumi, populasi mereka telah menurun dengan cepat di seluruh Pulau Sumatera.

Deforestasi didorong minyak-dokumen laporan bubur kayu-dan kelapa dan degradasi hutan alam dan menunjukkan bagaimana yang menyebabkan dekomposisi dan pembakaran tanah yang kaya karbon di lahan gambut Riau yang luas dan mendalam. Hal ini mengakibatkan emisi CO global yang signifikan dan banyak dilaporkan lintas batas kabut asap di Selat Malaka. Dan itu telah mengancam kepunahan lokal gajah Sumatera dan harimau, terutama karena peningkatan konflik manusiasatwa liar seperti binatang Riau memiliki hampir 900.000 hektar "limbah" tanah di mana perkebunan berpotensi dikembangkan tanpa memotong hutan lebih alami. Studi ini memperkirakan emisi historis dan masa depan CO terkait dengan deforestasi, degradasi hutan, degradasi tanah gambut dan pembakaran (sengaja menggunakan api di pembukaan lahan dan "pelarian" kebakaran).

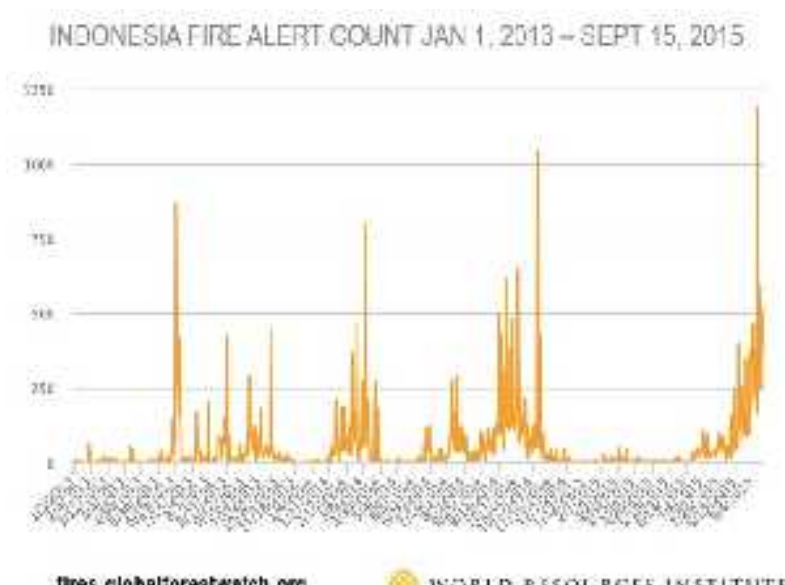

Gambar 1. Indeks Peringatan Siaga kebakaran Indonesia

Meskipun fakta itu ilegal untuk membakar hutan di Indonesia (kecuali untuk petani lokal sangat kecil), pembakaran sering digunakan untuk membersihkan lahan untuk pertanian dan komoditas ekspansi, Atau sebagai "Senjata" dalam konflikatas tanah. Lebih dari setengah dari kebakaran yang terjadi di lahan gambut yang kaya karbon, menyebabkan kabut asap parah dan kabut. Polusi dari kebakaran di provinsi Sumatera dan Riau Provinsi mengarah ke dialihkan dan dibatalkan penerbangan dan dampak kesehatan yang meluas. Pada minggu lalu,Indeks kualitas udara menyeberang ke "tingkat berbahaya" di lokasi di Sumatera dan Provinsi Riau. Ditingkat berbahaya kualitas udara, Seluruh penduduk mungkin akan terpengaruh, dan ini dianggap sebagai kondisi darurat. Ribuan orang telah dilaporkan 
meninggalkan Pekanbaru di Provinsi Riau untuk melarikan diri tingkat polusi udara rekor.

Hanya bagaimana pemerintah Indonesia harus mengatasi kebakaran adalah masalah mendesak. Presiden Jokowi melakukan kunjungan kejutan ke daerah konsesi di Sumatera Selatan pekan ini, dan berjanji untuk mencabut izin perusahaan ditemukan ilegal menggunakan api untuk membersihkan lahan. Kebakaran telah terjadi di Sumatera dan Riau Provinsi, dengan konsentrasi yang signifikan di Bengkalis, Provinsi Riau Barat; dan Pulau Kabupaten Padang di Provinsi Riau Tengah. Sebuah keadaan darurat telah dinyatakan untuk Provinsi Riau, tapi jauh lebih kebakaran dan kualitas udara sama miskin telah diamati di Sumatera Selatan, Jambi, dan Barat dan Provinsi Riau Tengah. Dampak ini lebih luas daripada yang terlihat di episode kebakaran sebelumnya, dan memperluas perhatian publik dan permintaan untuk pencegahan kebakaran lebih efektif dan respon dari instansi pemerintah, perusahaan dan lain-lain.

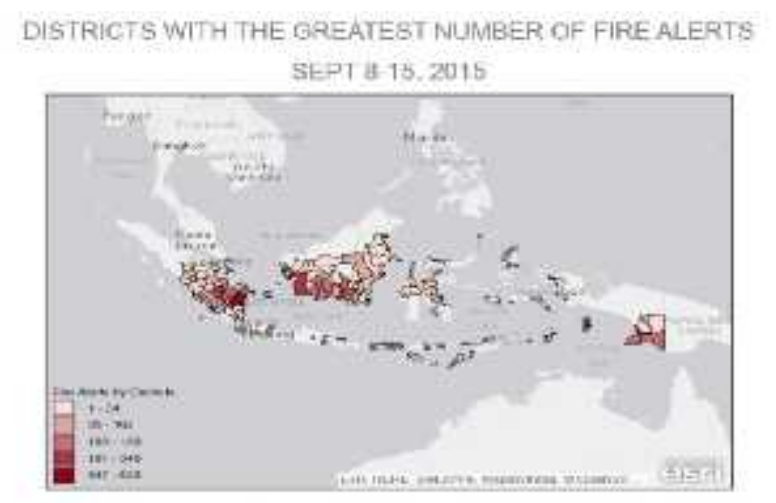

Gambar 2. Peta kabupaten dengan jumlah peringatan kebakaran terbesar

Kebakaran di taman nasional dan kawasan lindung lainnya juga menyoroti masalah dengan penegakan hukum. kebakaran meluasterjadi di Taman Nasional Tesso Nilo selama bulan Juli dan Agustus, dan sekarang membara di Taman Nasional Tanjung Putingdan beberapa kawasan lindung lainnya. Taman ini secara global penting untuk keanekaragaman hayati mereka, dan memberikan beberapa habitat yang tersisa untuk spesies seperti orangutan, gajah Sumatera dan macan tutul.

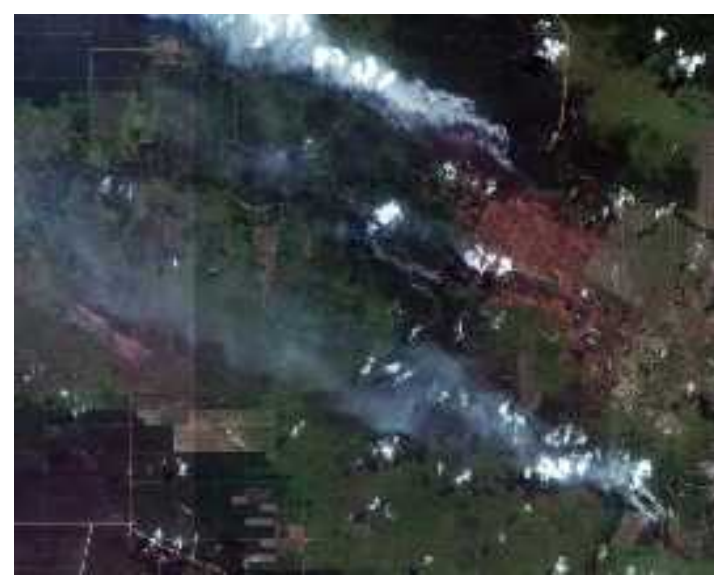

Gambar 3. Api aktif yang terbakar di tengah pembangunan perkebunan di Sumatera Selatan pada tanggal 10 September ditangkap di gambar ini oleh Digital Globe WorldView-2 satelit. (Lat -3,275, Lon 105,75; melihat api aktif di lokasi ini pada Kebakaran GFW)

Indonesia sering mengalami wabah lahan hutan dan kebakaran-terutama selama musim bukti-dan satelit kering menunjukkan kebakaran masalah masih jauh dari terselesaikan. Mengatasi krisis akan membutuhkan mendesaktindakan penegakanuntuk menahan orang-orang yang melakukan pembakaran atau mengelola lahan akuntabel dan mencegah orang lain dari pembakaran masa depan. Tapi mengendalikan kebakaran besar setelah mereka membakar seluruh daerah besar sangat sulit.

Pemerintah perlu memprioritaskan, tidak seperti sebelumnya, upaya untuk mencegah kebakaran di tempat pertama, jika wilayah ini akan menderita berulang kali selama bertahuntahun yang akan datang. Hal ini memerlukan keterlibatan berkelanjutan dengan petani lokal dan pemerintah daerah untuk mengatasi konflik atas tanah; penegakan hukum jauh lebih efektif, termasuk terhadap orang-orang yang mungkin koneksi politik atau lokal yang kuat; dan klarifikasi sistematis dan pemetaan tanah dan kepemilikan sumber daya dan tanggung jawab.

Kegiatan penebangan, drainase, kebakaran, konversi menjadi perkebunan dan perluasan kecil-pemegang didominasi lanskap mosaik telah meningkat pesat di daerah lahan gambut sejak tahun 1980-an (Silvius dan Diemont 2007). Kegiatan yang merusak tidak hanya mengganggu fungsi ekosistem, tetapi 
mempengaruhi fluks gas antara daerah lahan gambut dan suasana. Selain mengurangi jumlah biomassa yang dikandung oleh vegetasi hidup, kegiatan di lahan gambut menyebabkan perubahan tingkat air, yang mempengaruhi gambut dekomposisi dan karbon fluks dari gambut (Jauhiainen et al.2005). Secara tidak langsung, degradasi ekosistem lahan gambut membuat mereka lebih rentan terhadap aktivitas kebakaran tahunan (Cochrane2001; Siegert et al.2001) Dan meningkatkan risiko episode kebakaran parah berkala yang melepaskan jumlah tinggi karbon ke atmosfer (Page et al. 2002; Heil et al.2006).

Lahan gambut Sumatera dan Provinsi Riau terus memiliki berbagai fungsi ekologis, hidrologis dan biokimia dan nilai-nilai sosial (Rieley dan Halaman 2005) Lebih banyak di lokal di tingkat regional. Dalam beberapa tahun terakhir, hutan lahan gambut yang tersisa juga telah menjadi tempat perlindungan yang semakin penting untuk spesies hewan yang terancam punah (lihat misalnya MorroghBernard et al.2003), Karena menyusut daerah hutan dataran rendah pada tanah mineral.

Penelitian multi-disiplin, dinamika ekosistem lahan gambut tropis di Asia Tenggara kepulauan semakin dipahami dengan baik pada skala kecil. Sangat penting untuk memahami dampak tingkat lokal degradasi lahan gambut dan pengembangan (misalnya Kool et al.2006; Wösten et al.2006) Untuk dapat memperkirakan konsekuensi regional. Selanjutnya, informasi tentang fluks gas di kedua terganggu (misalnya Jauhiainen et al.2005) Dan terganggu (misalnya Hirano et al. 2007; Jauhiainen et al.2008) Kondisi yang diperlukan untuk estimasi emisi gas dengan konsekuensi yang berpotensi global. Namun, hasil penelitian skala kecil tidak dapat dipercaya disebarkan ke tingkat regional tanpa skala besar penilaian resolusi spasial tinggi status keseluruhan degradasi dan pembangunan di lahan gambut.

Kondisi cuaca terus-menerus berawan di kawasan Asia Tenggara tropis lembab, akuisisi resolusi tinggi $(<30 \mathrm{~m})$ cakupan citra satelit untuk studi skala besar sangat sulit. Sampai saat ini, tidak ada klasifikasi tutupan lahan skala besar berdasarkan data resolusi tinggi dengan skema klasifikasi yang dirancang untuk lahan gambut telah diterbitkan di Asia Tenggara kepulauan. Diterbitkan resolusi tinggi klasifikasi tutupan lahan di daerah lahan gambut di Sumatera dan Provinsi Riau telah dalam banyak kasus menjadi bagian dari studi skala kecil (misalnya Raja2002; Halaman et al.2002; Miettinen dan Liew2005; Wösten et al.2006) Dan dalam satu kasus bagian dari umum Sumatera klasifikasi tutupan lahan (Laumonier.1997).

Artikel ini, kita akan melaporkan hasil penilaian resolusi tinggi dari status degradasi lahan gambut dan pembangunan di Sumatera dan Provinsi Riau. Informasi ini berasal dari interpretasi visual dari 94 resolusi tinggi (10-20 m) Satellite Pour l'Observation de la Terre (SPOT) gambar menggunakan skema klasifikasi dengan 12 kelas khusus dirancang untuk daerah lahan gambut di Asia Tenggara kepulauan.

\section{BAHAN DAN METODE}

Penelitian ini menggunakan metode kualitatif dengan menggunakan murni dengan etnografi sebagai cara pengumpulan data. Sejumlah informan kunci diwawancarai secara terbuka sesuai dengan pertanyaan penelitian yang dirancang. Tapi untuk mengeksplorasi fenomena sosial yang sebenarnya terjadi dalam metode penelitian masyarakat membumi saya. Untuk mencari arti dari kegiatan budaya ritual dan masyarakat harus diangkat secara keseluruhan unsur-unsur yang membentuk budaya masyarakat terhadap lingkungan hidup mereka. Di Kabupaten Kampar, kita akan melihat dua praktek adat dari dua desa, yaitu: Desa Domo dengan "Lubuk Larangan", dan Desa Rumbio dengan konsep adat: Rimbo Larangan. Mengurangi dekomposisi narasi deskriptif untuk menjelaskan keberadaan dua konsep yang merupakan penerapan adat: pengetahuan ekologi tradisional di masyarakat adat Indonesia.

Whaterver, teknologi digunakan untuk mengumpulkan data penelitian ini. daerah ini, GPS mendapatkan 94 resolusi spasial tinggi (10-20 m) citra satelit SPOT yang digunakan dalam penelitian ini. Karena kondisi yang sangat berawan, tanggal akuisisi perlu tersebar di beberapa tahun. Empat dari gambar diperoleh pada tahun 2005 (Januari 20, Maret 14, Juli 13 dan 7 Agustus). Tanggal akuisisi untuk 90 gambar yang tersisa berkisar antara 28 Januari 2006 dan 17 Oktober 2008. Dari jumlah 
tersebut, 24 gambar ditangkap pada tahun 2006, 43 pada tahun 2007 dan 23 pada tahun 2008. Dengan set data ini, kami mampu menutupi $83 \%$ ( 10,804 Mha) dari total 12,974 Mha dari lahan gambut di Sumatera dan Provinsi Riau, termasuk semua area lahan gambut utama. gambar bebas awan untuk sisa daerah yang tidak tersedia.

Dua belas dari citra satelit yang digunakan dalam penelitian ini diakuisisi oleh SPOT 2 Resolusi Tinggi Terlihat sensor (HRV), 43 dengan SPOT 4 Resolusi Tinggi Visible dan Infrared (HRVIR) sensor dan 39 oleh SPOT 5 Resolusi Tinggi Geometric (HRG) sensor. 20-m resolusi SPOT 2 sensor HRV memiliki tiga band panjang gelombang: hijau (Band 1: 0,500,59 m), merah (pita 2: 0,61-0,68 pM) dan inframerah dekat (band 3: 0,79-0,89 pM). Selain tiga band ini, 20-m resolusi SPOT 4 HRVIR dan 10-m sensor resolusi SPOT 5 HRG memiliki sebuah band keempat dalam kisaran inframerah gelombang pendek dari spektrum elektromagnetik (band 4: 1,53-1,75 pM). Citra satelit yang diterima dan diolah untuk tingkat 2A (radiometrik dan koreksi geometrik) oleh Center for Remote Imaging, Sensing dan Pengolahan (CRISP) di National University of Singapore (NUS).

\section{HASIL}

\section{Klasifikasi Tutupan Lahan dan Tingkat Degradasi}

Lahan gambut yang digariskan oleh Wahyunto et al. (2003. 2004) Dan ditutupi oleh data satelit bebas awan yang secara visual diperiksa, dan poligon tutupan lahan secara manual didigitalkan di layar. Meskipun telah menyarankan bahwa peta distribusi lahan gambut tersebut di atas mungkin meremehkan luasnya lahan gambut sebanyak 10\% (Jaenicke et al.2008), Tidak ada koreksi atau modifikasi peta tersebut berusaha dalam penelitian ini. Hal ini dianggap sebagai pendekatan terbaik untuk menjaga konsistensi data, pengulangan dari penelitian dan perbandingan dengan penelitian lain berdasarkan peta yang sama. keputusan ini, bagaimanapun, diperhitungkan dalam interpretasi hasil penelitian ini.

Tiga band yang digunakan untuk SPOT 2 HRV gambar (RGB: 321) dan band dua, tiga dan empat untuk SPOT 4 HRVIR dan SPOT 5
HRG gambar (RGB: 432). Kombinasi ini dianggap untuk memberikan keterpisahan terbaik untuk jenis tutupan lahan yang berbeda. Penggambaran tutupan lahan dan tingkat degradasi poligon dilakukan dalam 1: 100.000 skala. Dalam rangka untuk mendapatkan hasil klasifikasi yang konsisten di seluruh daerah studi, semua pekerjaan klasifikasi dilakukan oleh satu orang. penafsir telah bekerja di lapangan di beberapa situs di wilayah studi (di Riau, Jambi dan Provinsi Riau Central provinsi) dan memiliki pengalaman yang luas di visual yang interpretasi citra satelit dari lahan gambut tropis dengan gambar resolusi tinggi.

Skema klasifikasi dirancang berdasarkan tinjauan literatur (misalnya Page et al. 2002; Rieley dan Page. 2005; Wösten et al. 2006; Corlett 2009) serta pengalaman pribadi penulis membuat konseptualisasi pada kunjungan lapangan ke berbagai jenis tutupan lahan. Penelitian ini dilakukan dengan dua langkah yaitu pertama, semua kawasan hutan yang tersisa digambarkan, dan daerah non-hutan diklasifikasikan menjadi delapan kelas yang menggambarkan jenis tutupan lahannya. Pada langkah kedua, semua kawasan hutan diklasifikasikan menjadi empat tingkatan yang berbeda dari degradasi berdasarkan pada jumlah tanda-tanda campur tangan kegiatan manusia. Angka- angka itu menggambarkan gaya klasifikasi akhir.

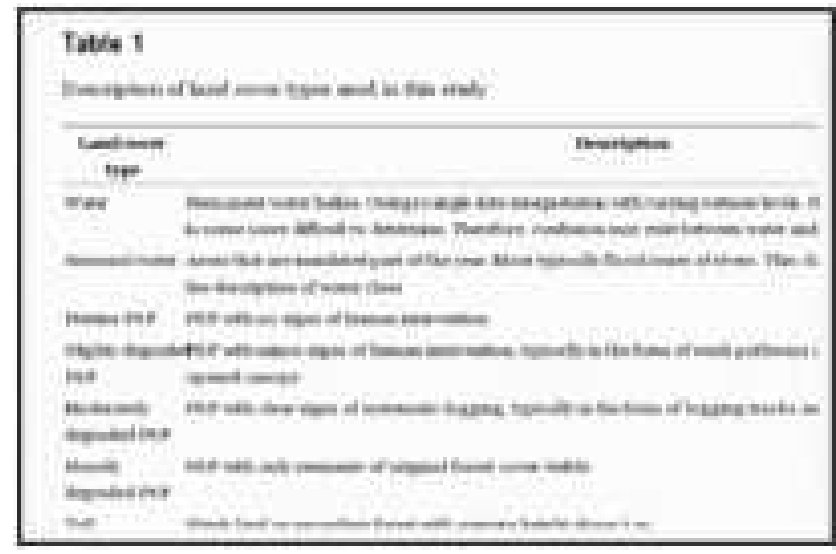

Gambar 3. Deskripsi jenis tutupan lahan yang digunakan dalam penelitian ini 


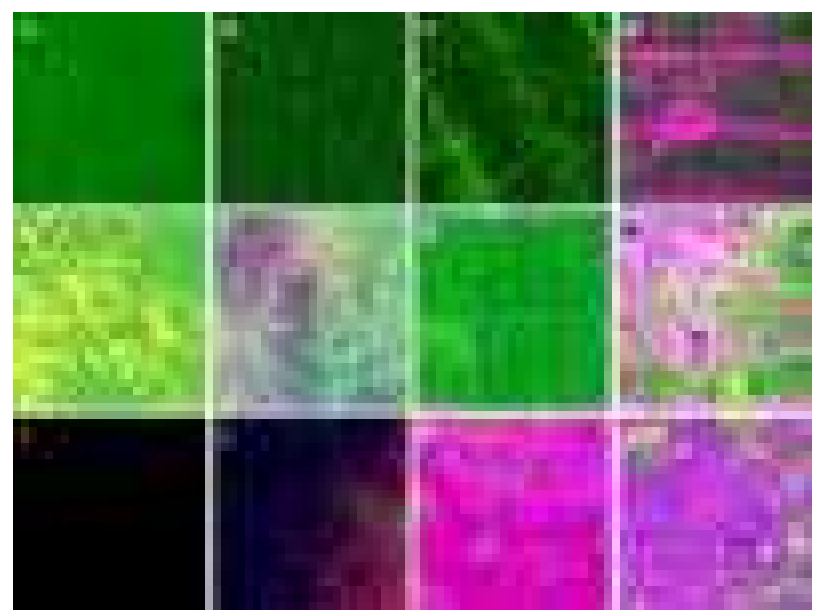

Gambar 4. Contoh tingkat degradasi hutan dan jenis tutupan lahan yang digunakan dalam klasifikasi penelitian. Gambar (a) lahan masih murni PSF, (b) lahan sedikit terdegradasi PSF, (c) cukup terdegradasi PSF, (d) terdegradasi berat PSF, (e) tinggi semak / hutan sekunder atau pakis-pakisan; (f) semak rendah dan $(\mathrm{g})$ hutan tanaman industri
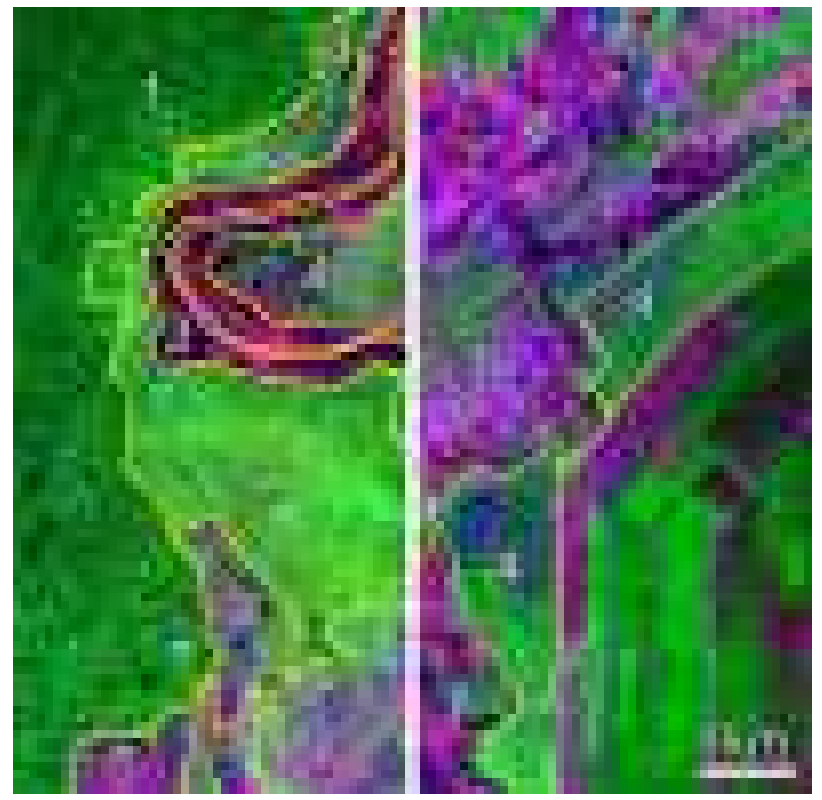

Gambar 5. Contoh klasifikasi akhir overlay pada citra satelit SPOT. Garis kuning pada tanah sebagai perbatasan penutup poligon. Jenis tutupan lahan yang terlihat di Provinsi Riau (kiri) dan Sumatera Selatan (kanan) gambar meliputi: lahan terdegradasi cukup tinggi.
Tujuannya adalah untuk menyertakan fase utama degradasi lahan gambut tropis dan proses pembangunan ke dalam skema klasifikasi sambil menjaga cukup sederhana untuk menjaga keandalan hasil. Kesederhanaan dan keandalan klasifikasi dianggap sangat penting karena data lapangan yang cocok untuk penilaian akurasi untuk skala besar tetapi studi resolusi tinggi seperti ini tidak dapat diperoleh karena daerah penelitian yang luas dan aksesibilitas rendah dari lahan gambut tropis. Sumber terbesar dari kesalahan dalam visual yang / pendekatan klasifikasi manual yang digunakan dalam penelitian ini dianggap sebagai generalisasi yang tidak disengaja dari garis perbatasan antara jenis tutupan lahan (lihat overlay pada Gambar 5). Namun, sumber kesalahan ini tidak akan menyebabkan bias yang signifikan dalam statistik tutupan lahan karena jenis kesalahan cenderung mengimbangi dalam dataset besar. Namun, karena masalah yang disebutkan di atas dan karena periode akuisisi data lama, angkaangka yang disajikan dalam artikel ini tidak harus diambil sebagai nilai absolut dari tingkat atau proporsi kelas tutupan lahan, tetapi lebih sebagai indikator dari distribusi tutupan lahan umum di lahan gambut Provinsi Riau

\section{PEMBAHASAN}

Lahan gambut tropis menutupi seluruh dunia sekitar 45 juta hektar. Daerah lahan-lahan terbesar rawa gambut dunia agak sukar diketahui tapi khusus di Asia Tenggara sedang berada di bawah ancaman serius. Diantara ancaman tersebut adalah dari pembersihan lahan yang tanpa kaedah alam, degradasi dan titik api, sehingga membahayakan fungsi alami mereka sebagai reservoir keanekaragaman hayati, stok karbon dan penyangga hidrologi. Pemanfaatan sumber daya ini untuk tanaman pertanian atau perkebunan membutuhkan drainase itu, mau tidak mau, mengarah ke penurunan ireversibel dryng yang mengakibatkan gambut mengemisi $\mathrm{CO} 2$ ke atmosfer. Ketika emisi berterusan, dapat menghasilkan gangguan parah substrat dan menciptakan masalah untuk budidaya dan kehidupan masyarakat

Dari semua lahan gambut yang dipetakan, sekitar $41 \%$ ditempati oleh hutan rawa gambut (PSF) (Gambar 4). Dengan demikian, setidaknya 4,4 juta ha dari lahan gambut masih 
tertutup oleh PSF baik di Sumatera Selatan dan Provinsi Riau. Namun, sebagian besar PSF dianggap cukup baikterdegradasi PSF menunjukkan tanda-tanda yang jelas dari penebangan sistematis dalam bentuk logging atau kanal dan / atau membuka kanopi (Gambar 4 d), atau PSF sangat terdegradasi dengan hanya sisa-sisa ekosistem hutan asli kiri (Gambar $4 \mathrm{~g}$ ). Kurang dari $11 \%$ dari lahan gambut tetap ditutupi dengan PSF hanya menampilkan minor tutupan lahan (Gambar 4f) atau tidak tandatanda aktivitas manusia(Gambar 4.c)

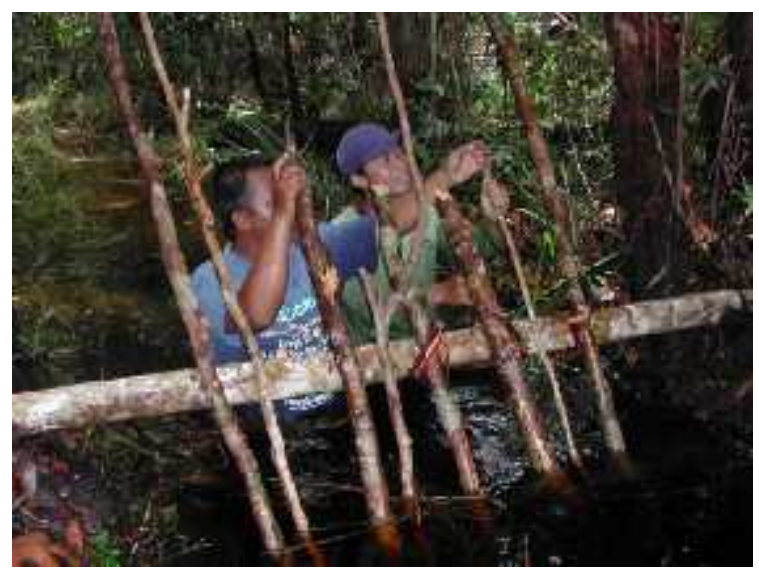

Gambar 6. Pembuatan Kanal Blocking untuk rewetting (pembasahan) rawa gambut di Propinsi Riau

Proporsi kawasan hutan yang tersisa bervariasi antara Sumatera dan Provinsi Riau. Sementara sekitar setengah dari lahan gambut yang dipetakan di Provinsi Riau ditutupi oleh hutan, hanya sepertiga tetap sebagai PSF di Sumatera (gambar 4.d). Ini harus ditunjukkan dalam konteks ini, bagaimanapun, bahwa beberapa PSFs paling utuh dan tak terganggu di daerah penelitian ditemukan di Sumatera, terutama di provinsi-provinsi Riau dan Jambi. Namun, Provinsi Riau memiliki kawasan hutan secara keseluruhan lebih besar dengan setidaknya 2,2 Mha dari sedikit atau sedang terdegradasi kiri PSF (sebagai lawan 1,5 Mha di Sumatera).

Sejauh daerah penelitian seluruh yang bersangkutan, sebagian besar wilayah yang tidak berhutan ditutupi oleh dikelola jenis tutupan lahan, terutama oleh baik pertanian kecil-pemegang atau hutan tanaman industri (Tabel2). hutan tanaman industri menutupi setidaknya 1,4 Mha di lahan gambut Sumatera dan Provinsi Riau. Namun, distribusi dikelola jenis tutupan lahan antara Sumatera dan Propinsi Riau menyoroti perbedaan umum dalam tingkat pembangunan lahan gambut di kedua daerah. Di Sumatera, hampir setengah dari lahan gambut dikelola dan ditutupi oleh salah pertanian kecil-pemegang $(24 \%)$ atau hutan tanaman industri (21\%). Sedangkan di Provinsi Riau, hanya 14\% dari daerah yang ditempati oleh jenis tutupan lahan yang dikelola tersebut, areal perkebunan hampir melebihi $2 \%$ (Tabel 4.c). Sebaliknya, lahan gambut nonhutan didominasi oleh landscape terdegradasi unmanaged, yang mencakup hampir seperempat dari semua lahan gambut di Provinsi Riau.

\section{Pendekatan Pengetahuan Ekologi Tradisional}

Pengetahuan ekologi tradisional (TEK) atau kadang-kadang disebut sebagai pengetahuan lingkungan tradisional $\sim$ sering digambarkan sebagai wawasan lokal dan holistic. Ia mengintegrasikan fisik dan spiritual menjadi pandangan dunia atau "cosmovision" yang telah berkembang dari waktu ke waktu dan menekankan aplikasi praktis dari keterampilan dan pengetahuan. TEK adalah produk dari pengamatan yang cermat dan tanggapan yang pernah perubahan kondisi lingkungan dan sosial-ekonomi: seperti yang kita ketahui, adaptasi adalah kunci untuk kelangsungan hidup.

Ada sedikit keraguan bahwa TEK memiliki potensi besar untuk wawasan dan teknik di bidang kelautan dan manajemen agroekosistem asalkan tidak diambil di luar konteks atau terpuntir untuk tujuan eksploitasi. Prinsip 22 dari Deklarasi Rio tentang Lingkungan dan Pembangunan menyatakan bahwa:

masyarakat adat dan masyarakat mereka dan masyarakat lokal lainnya memiliki peran penting dalam pengelolaan lingkungan hidup dan pembangunan karena pengetahuan dan praktek-praktek tradisional. Negara harus mengakui dan sepatutnya mendukung identitas, budaya dan kepentingan dan memungkinkan partisipasi efektif mereka dalam pencapaian pembangunan berkelanjutan.

TEK sebagai konsep modern memiliki kelahirannya pada pernikahan ethnobiologi dan ekologi manusia diawali dengan studi spesies lokal dan klasifikasi mereka, dan maju (dalam lingkup) untuk memahami proses dan hubungan 
ekologi. Seperti yang didefinisikan oleh Konvensi Keanekaragaman Hayati, Pasal 8 (j): pengetahuan tradisional mengacu pada pengetahuan, inovasi dan praktek masyarakat adat dan lokal di seluruh dunia. Dikembangkan dari pengalaman yang diperoleh selama berabad-abad dan disesuaikan dengan budaya lokal dan lingkungan, pengetahuan tradisional ditularkan secara lisan dari generasi ke generasi. Hal ini cenderung untuk dimiliki secara kolektif dan mengambil bentuk cerita, lagu, cerita rakyat, peribahasa, nilai-nilai budaya, keyakinan, ritual, hukum masyarakat, bahasa lokal, dan praktek-praktek pertanian, termasuk pengembangan spesies tanaman dan keturunan hewan. pengetahuan tradisional terutama yang bersifat praktis, khususnya di bidang-bidang seperti pertanian, perikanan, dan untuk pemulihan degradasi lahan Provinsi Riau, Indonesia.

Menurut wawancara mendalam dengan Tenas Effendy (2003) kita harus pengantar untuk konsep malay tentang hubungan antara pandangan adat dengan hewan dan konservasi tumbuhan. Itu adalah pendekatan holistik:

"Pantang menebang kayu tunggal-tunggalan pantang menebang kayu kayan sedang berbuah

pantang menebang kayu peneduh pantang menebang kayu sempadan pantang menebang kayu pengobat pantang menebang kayu bergeta pantang menebang kayu sialang pantang menebang kayu berdamar

pantang menebang kayu bergaharu dll"

Dalam pernyataan ini, sifat dari orangorang Melayu yang menjauhkan, sopan dan tidak memaksa menghasilkan saran budaya lembut begitu banyak. Sementara budaya barat dan paradigma bandar modern yang mengabdikan nyata identitas, indeks pengukuran ketat, hutan menyimpan kekal, jumlah statistik / index hewan dan tumbuhan yang tersimpan, deretan staples di jalan, penilaian dampak lingkungan, dan pengaturan dengan pendekatan akal rasional. Justru perspektif yang tersirat, dalam kasus kosmologi malay di Kampar untuk menggambarkan sikap penuh kasih ke lingkungan. Sebaliknya mereka mengambil kontemplasi dari mencolok korban alam di pepatah: studi lingkungan, biasanya hewan dan tanaman di hutan mengambil tempat seperti temperamen, atau perilaku dan moralitas manusia, sehingga orang dapat mengambil yang positif dan meninggalkan yang buruk daripada sifat tanaman di hutan.

Dan dia mengatakan bahwa:

"Kalau hendak industri tahu Sifat Manusia, tengok-tengoklah kayu di rimba

Ada Yang gede ADA Yang Kecil

Ada Yang Tinggi ADA Yang Rendah

Ada Yang lurus ADA Yang bengkok

Ada Yang Hidup tindih menindih

Ada Yang Hidup belit membelit

Ada Yang Berduri ADA Yang TIDAK

Ada Yang berlumut ADA Yang Licin

Ada Yang bergetah ADA Yang Berbisa

Ada Yang miang ADA Yang Gatal

Ada Yang Beracun ADA Yang Penawar

Ada Yang berbuah ADA meranggas Yang

Ada Yang elok ADA Yang buruk

Ada Yang berlubang ADA Yang berbongkol

(Jika Anda ingin mengetahui sifat manusia, melihat kayu di hutan!)

Ada besar dan kecil

Ada-tinggi rendah

Ada beberapa lurus bengkok

Ada kehidupan menekan tumpang tindih

Ada kehidupan konvolusi berbelit-belit

Ada satu berduri tidak

Ada beberapa berlumut licin

Ada beberapa getah beracun

Ada gatal yang "Miang"

Ada penangkal yang beracun

Ada berbuah satu meranggas

Tidak ada yang buruk yang chic

\section{Ada lubang ada yang " berbongkol" )}

Konseptualisasi ruang dan habitat di budaya Melayu didasarkan pada keyakinan diartikulasikan melalui berbagai media. budaya modern yang menyajikan mereka dalam bentuk rencana dan peta yang sering menekankan efisiensi subdivisi kepemilikan lahan, ruang publik dan swasta serta potensi investasi ekonomi sosial. pengetahuan ekologi tradisional di Kampar di sisi lain mempresentasikan ide mereka tentang ruang dan habitat melalui tradisi lisan serta tertulis. Beberapa menyajikan konsep mereka melalui lagu, cerita dan motif yang indah bersama dengan media umum lainnya. Dalam studi ini, hadir untuk basis budaya atau konservasi Melayu tradisional disajikan 
awalnya melalui tradisi lisan, melalui mitos dan kosmologi. Ide pembuatan tempat dan bangunan lingkungan lebih dari sekedar fisik; mereka sangat sosial di alam.

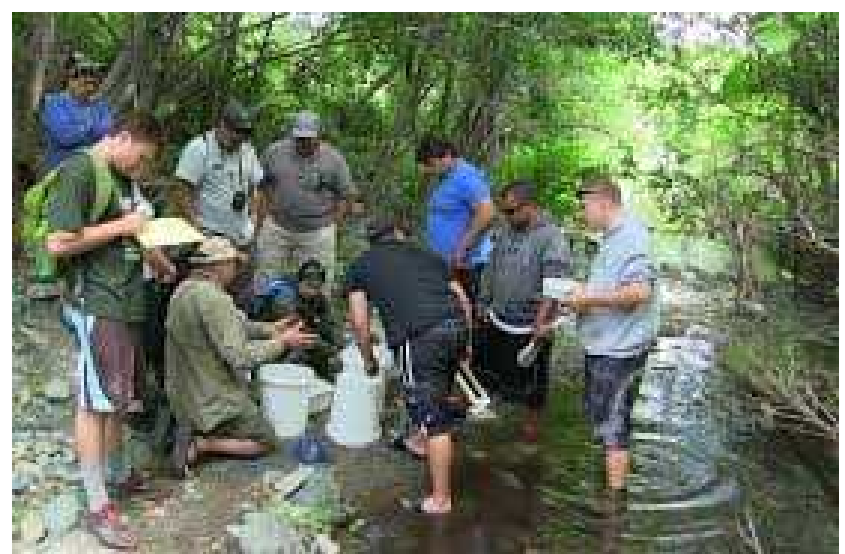

Gambar 7. Masyarakat dan peneliti mencatat kadar kebasahan gambut setelah dilakukan kanal bloking

Hasil yang disajikan dalam artikel ini menyoroti (1) status keseluruhan ekosistem lahan gambut yang mengkhawatirkan di Sumatera dan Provinsi Riau dan (2) variabilitas yang besar dari degradasi dan tingkat pengembangan di kawasan ini. Sementara $41 \%$ (4,4 Mha) dari lahan gambut di Sumatera dan Provinsi Riau masih tertutup oleh PSFs, hanya $11 \%$ (1,2 Mha) diperkirakan akan ditutupi oleh hutan relatif utuh. Karena meningkatnya kerentanan kebakaran hutan yang rusak (Goldammer1999; Siegert et al.2001; Halaman et al.2009), Ini menempatkan sebagian besar PSFs tersisa pada risiko tinggi kebakaran dan degradasi lebih lanjut selama musim kering.

Kawasan hutan yang tersisa terkonsentrasi di Provinsi Riau, sedangkan lahan gambut Sumatera telah dikonversi menjadi budidaya yang lebih luas. Dari semua 1,4 Mha hutan tanaman industri dipetakan, hanya 0,1 Mha terletak di Provinsi Riau. Demikian pula, daerah yang didominasi kecil-pemegang menutupi lahan gambut hampir tiga kali lebih di Sumatera daripada di Provinsi Riau. Perbedaan-perbedaan dalam tingkat pembangunan dapat dijelaskan sebagian besar dengan distribusi penduduk dan aksesibilitas lahan gambut. Terlepas dari asalusul perbedaan jelas, tingkat perkembangan saat ini menempatkan Sumatera dan Provinsi Riau ke posisi yang sangat berbeda dari perspektif pengelolaan lahan gambut.
Dengan pengelolaan lahan gambut berkelanjutan, masih akan ada kemungkinan untuk mempertahankan hampir setengah dari semua lahan gambut di Provinsi Riau sebagai PSF dan dengan demikian mencoba untuk mempertahankan fungsi dan nilai-nilai ekosistem, serta mencegah emisi karbon ke atmosfer. Fitur yang paling mengkhawatirkan dari lahan gambut Provinsi Riau adalah jumlah lahan gambut terdegradasi unmanaged yang telah menggantikan hutan biasanya hancur oleh kebakaran berulang (Langner dan Siegert2009; Halaman et al.2009). Pada sebagian besar daerah-daerah, vegetasi asli telah digantikan oleh pertumbuhan kembali mulai dari pakis hutan sekunder. Selain itu, keseimbangan permukaan air sering terganggu oleh drainase. Jenis lanskap sangat rentan untuk degradasi lebih lanjut dan sangat sulit untuk beregenerasi menjadi hutan (Page et al.2009). Berulang terbakar tidak hanya melarang regenerasi hutan tapi lebih combusts lapisan atas gambut, menurunkan tingkat permukaan. Dalam kasus terburuk, kebakaran berulang mengurangi daerah-daerah tersebut menjadi danau musiman lebih dari satu meter, meniadakan setiap upaya restorasi (Wösten et al.2006).

Di Sumatera, selain dari beberapa daerah PSF yang tersisa, perencanaan manajemen masa depan kemungkinan besar akan berkonsentrasi pada upaya untuk mempertahankan produktivitas dan kegunaan dari lahan gambut ditanami. daerah yang dibudidayakan meliputi pertanian skala kecil kelapa sawit, sagu, kelapa, nanas dll serta perkebunan industri berskala besar terutama kelapa sawit dan pulp. Secara keseluruhan, variasi dalam tingkat degradasi dan pengembangan melihat di kawasan ini menyoroti berbagai masalah dan program alternatif tindakan yang perencana pengelolaan lahan gambut harus menghadapi di berbagai bagian Sumatera dan Provinsi Riau saat ini.

\section{SIMPULAN}

Keberadaan tanah komunal adat; tanah atau tanah tempat penampungan setiap bentuk kearifan tradisional bersama-sama ada di darat, laut, hutan, sungai, sawah, ke tatanan sosial dan harmoni sesama warga. Di atas ini adalah tradisional komunal tanah-ide ide kebajikan dalam berurusan dengan alam sekitar pertemuan 
pemikiran yang jernih tradisional dari elders.Nature tradisional tidak untuk kepentingan material, demi hanya manusia dan makhluk hidup lainnya, tetapi berfungsi sebagai sumber inspirasi bagi humanisasi makhluk, pikiran, dan mempertinggi sifat. Perenungan makrokosmos keheningan alam mengembangkan ide untuk membuat sajak, saran budaya, "Seloka, petatah" pepatah, dan sumber nilai publik asli. Dengan perspektif humanis sedemikian rupa, maka teori baru ini menang menerima harapan inspirasi, menciptakan cucu masa depan suatu hari nanti.

Praktek pengelolaan hutan yang inovatif, berdasarkan pengetahuan tradisional dan dikembangkan oleh masyarakat lokal di Riau Indonesia, telah memberikan kontribusi signifikan terhadap warisan alam dan budaya dunia dengan menciptakan dan memelihara lanskap luar biasa keindahan sambil membantu untuk mempertahankan produksi beberapa barang dan jasa yang meningkatkan keamanan mata pencaharian dan kualitas hidup. Tradisional ekologi pengetahuan (hutan atau sungai di daerah studi) merupakan komponen integral dari jaringan keterkaitan dan hubungan, didukung oleh kerangka keseluruhan tandatanda dan makna. Hal ini sering didasarkan pada pengalaman panjang sejarah dan wawasan yang mendalam dinamika ekosistem hutan, dan perilaku dan karakteristik spesies hewan dan tumbuhan yang ekonomi, sosial, budaya, dan spiritual makna khusus bagi masyarakat. Ulasan ini merekomendasikan adalah ketika nilai-nilai tradisional dapat dikombinasikan dengan manajemen yang bijaksana dari pemerintahan modern, dapat ditemukan dalam konsep pembangunan berkelanjutan.

Konseptualisasi kelestarian lingkungan pada pengetahuan tradisional di kosmologi Melayu di Provinsi Riau didasarkan pada keyakinan diartikulasikan melalui berbagai media. Mereka adalah kesadaran berbagai aspek pengelolaan hutan dengan "alam terkambang sebagai guru"

Temuan yang tepat dari pengorganisasian masyarakat Melayu dan Melayu konsep puisi melambangkan kesopanan di alam. ekspresi yang indah memberikan pesan yang bermakna dalam sistem keluarga, tetangga, masyarakat dan bangsa. Komponen laut, darat dan langit sebagai sistem totalitas tidak terlepas dari sistem manusia yang sinyal kebiasaan, hukum, dan iman diperkuat pagar bahwa orang-orang dari segala macam godaan, cobaan, dan serangan yang terbentang di depan.

Tanpa disadari, memang komunitas riset ini telah memainkan peran penting dalam menjaga ekosistem, merawat dan melestarikan lingkungan dengan konsep yang sangat efektif. Konsep ini akan berbenturan dengan ilmu pengetahuan modern ke dalam arus utama pembangunan berkelanjutan.

\section{UCAPAN TERIMA KASIH}

Ucapan terima kasih penulis ucapkan kepada pihak-pihak yang telah membantu dalam terlaksananya penelitian ini.

\section{DAFTAR PUSTAKA}

Chan, YK, XW Lim, dan J. Miettinen. 2010. Analisis vegetasi distribusi kebakaran di Asia Tenggara kepulauan pada tahun 2009. Dalam Prosiding Program Scientist Pertahanan Muda (YDSP) Congress 2010, 8 April 2010, Singapura.

Cochrane MA. interaksi sinergis antara fragmentasi habitat dan api di hutan tropis hijau. Biologi Konservasi. 2001; 15: 1515-1521. doi: 10,1046 / j.15231739.2001.01091.x. [Palang Ref]

Corlett RT. Ekologi tropis Asia Timur. New York: Oxford University Press; 2009.

Goldammer JG. Hutan terbakar. Sains Seri Baru. 1999; 284: 1782-1783.

Heil A, Langmann B, Aldrian E. gambut dan vegetasi emisi api Indonesia: Studi pada faktor-faktor yang mempengaruhi pencemaran kabut asap skala besar menggunakan model kimia atmosfer regional. Strategi Mitigasi dan Adaptasi Perubahan Global. 2006; 12: 113-133. doi: 10,1007 / s11027-006-9045-6. [Palang Ref]

Hirano T, Segah H, Harada T, Limin S, Juni T, Hirata R, keseimbangan dioksida Osaki M. Karbon dari hutan rawa gambut tropis di Provinsi Riau, Indonesia. Global Change Biology. 2007; 13: 412-425. doi: 10,1111 / j.1365-2486.2006.01301.x. [Palang Ref] 
Jaenicke J, Rieley JO, Mott C, Kimman P, Siegert F. Penentuan jumlah karbon yang tersimpan di lahan gambut Indonesia. Geoderma. 2008; 147: 151-158. doi: 10,1016 / j.geoderma.2008.08.008. [Palang Ref]

Jauhiainen J, Limin S, Silvennoinen H, Vasander H. Karbon dioksida dan metana fluks di gambut tropis dikeringkan sebelum dan sesudah restorasi hidrologi. Ekologi. 2008; 89: 3503-3514. doi: 10,1890 / 07-2038,1. [PubMed] [Palang Ref]

Jauhiainen J, Takahashi H, Heikkinen JEP, Martikainen PJ, fluks Vasander H. Karbon dari lantai hutan rawa gambut tropis. Global Change Biology. 2005; 11: 17881797. doi: 10,1111 / j.13652486.2005.001031.x. [Palang Ref]

Raja RB. Tanah prinsip pemetaan tutupan: A kembali ke dasar-dasar penafsiran. International Journal of Remote Sensing. 2002; 23: 3525-3545. doi: 10,1080 / 01431160110109606. [Palang Ref]

Kool DM, Buurman P, Hoekman DH. Oksidasi dan pemadatan dari kubah gambut yang runtuh di Provinsi Riau Tengah. Geoderma. 2006; 137: 217-225. doi: 10,1016 / j.geoderma.2006.08.021. [Palang Ref]

Langner A, Siegert F. Spatiotemporal terjadinya kebakaran di Kalimantan selama 10 tahun. Global Change Biology. 2009; 15: 48-62. doi: 10,1111 / j.1365-2486.2008.01828.x. [Palang Ref]

Morrogh-Bernard H, Husson S, Halaman SE, Rieley JO. Status populasi orangutan Borneo (Pongo pygmaeus) di hutan rawa gambut Sebangau, Central Provinsi Riau, Indonesia. Konservasi biologi. 2003; 110 : 141-152. doi: 10,1016 / S0006-3207 (02) 00.186-6. [Palang Ref]

Halaman SE, Bank C. Tropical lahan gambut: Distribusi, luas dan penyimpanan karbonketidakpastian dan kesenjangan pengetahuan. Lahan gambut International. 2007; 2: 26-27.

Halaman SE, Hoscilo A, Wösten H, Jauhiainen J, Silvius M, Rieley J, Ritzema H, Tansey K, Graham L, Vasander H, Suwido L. Restorasi ekologi lahan gambut tropis dataran rendah di Asia Tenggara: pengetahuan saat ini dan arah penelitian masa depan. Ekosistem. 2009; 12: 888905. doi: 10,1007 / s10021-008-9216-2. [Palang Ref]

Halaman SE, Siegert F, Rieley J, Boehm H-DV, Jaya A, Limin S. Jumlah karbon dilepaskan dari gambut dan kebakaran hutan di Indonesia selama 1997. Nature. 2002; 420: 61-65. doi: 10.1038 / nature01131. [PubMed] [Palang Ref]

Rieley, JO, dan SE Page, eds. 2005. Penggunaan Wise lahan gambut tropis: Fokus di Asia Tenggara. Wageningen, Belanda: Alterra-Wageningen University dan Pusat Penelitian dan Uni Eropa INCO-STRAPEAT dan RESTORPEAT Kemitraan.

Siegert F, Ruecker G, Hinrichs A, Hoffmann AA. Peningkatan kerusakan dari kebakaran di hutan login selama kekeringan disebabkan oleh El Nino. Alam. 2001; 414: 437-440. doi: 10.1038 / 35.106.547. [PubMed] [Palang Ref]

Silvius M, Diemont H. Deforestasi dan degradasi lahan gambut. Lahan gambut International. 2007; 2: 32-34.

Wahyunto, S. Ritung, dan H. Subagjo. 2003. Maps daerah distribusi lahan gambut dan kandungan karbon di Sumatera, 19902002. Bogor, Indonesia: Wetlands International-Indonesia Program \& Wildlife Habitat Canada (WHC).

Wahyunto, S. Ritung, Suparto, dan H. Subagjo. 2004. Peta wilayah distribusi lahan gambut dan kandungan karbon di Provinsi Riau, 2000-2002. Bogor, Indonesia: Wetlands International-Indonesia Program \& Wildlife Habitat Canada (WHC).

Wösten JHM, Berg J, Eijk P, Gevers GJM, Giesen WBJT, Hooijer A, Idris A, PH Leenman, Rais DS, Siderius C, Silvius MJ, Suryadiputra N, Wibisono IT. Hubungan timbal balik antara hidrologi dan ekologi dalam api terdegradasi hutan rawa gambut tropis. Pengembangan Sumber Daya Air. 2006; 22: 157-174. doi: 10,1080 / 07900620500405973. [Palang $\underline{\text { Ref] }}$ 